\title{
Characterization of Mineralogy, Petrography, Geochemistry and Petrogensis of Basaltic Outcrops in Jurf Ed Darawish Area, Central Jordan
}

\author{
Ibrahim Ahmad Ali Bany Yaseen \\ Department of Earth and Environmental Sciences, Institute of Earth and Environmental Sciences, Al-al-Bayt University, \\ Al-Mafraq, Jordan \\ Email: ibanyyaseen@aabu.edu.jo, ibanyyaseen@yahoo.com
}

How to cite this paper: Yaseen, I.A.A.B. (2019) Characterization of Mineralogy, Petrography, Geochemistry and Petrogensis of Basaltic Outcrops in Jurf Ed Darawish Area, Central Jordan. Open Journal of Geology, 9, 440-460.

https://doi.org/10.4236/ojg.2019.98029

Received: July 2, 2019

Accepted: August 25, 2019

Published: August 28, 2019

Copyright $\odot 2019$ by author(s) and Scientific Research Publishing Inc. This work is licensed under the Creative Commons Attribution International License (CC BY 4.0).

http://creativecommons.org/licenses/by/4.0/

\begin{abstract}
This research was conducted to investigate the mineralogy, petrography, geochemistry and petrogensis of the basaltic flows in Jurf Ed Darawish (JDB) area of central Jordan. Sexton representative basalt rock samples were selected from the studied JDB outcrops. Modally, JDB consists of plagioclase, olivine, pyroxene (diopside), opaque's, calcite and iddingsite minerals. Petrographically, basalt is holocrystalline, hypidiomorphic fine to medium grained and exhibited aphanitic to porphyritic texture. The common textures of the JDB rock samples were aphanitic, porphyritic, trachytic, glomeroporphyritic, sub ophitic, vesicular, and amygdaloidal. Geochemically, all of the inspected samples of JDB are located within Trachy basalt and plate alkaline basalt. The tectonic setting of JDB was plotted within the calcalkaline basalt and continental basaltic field. The rare-earth elements showed enrichment of the Ba and $\mathrm{K}$, depletion of Ce relative to $\mathrm{K}$, and enrichment of $\mathrm{Nb}$ and $\mathrm{Pb}$ with depletion of $\mathrm{Y}$ and positive $\mathrm{Nb}, \mathrm{Zr}$ and $\mathrm{Ti}$ anomalies. Negative anomalies of $\mathrm{Ba}$, $\mathrm{Sr}, \mathrm{Ti}$ and $\mathrm{P}$ may be attributed to the fractionation of feldspar for $\mathrm{Ba}$ and $\mathrm{Sr}$ depletion apatite for $\mathrm{P}$ depletion. The positive $\mathrm{Nb}$ peak conforms to the tertiary as well as to recent continental alkali basalt provinces and acts as an indicator to the JDB product for the lithosphere from upwelling of the asthenosphere mantle.
\end{abstract}

\section{Keywords}

Mineralogy, Petrography, Geochemistry, Petrogensis, Alkali Basaltic, Jurf Ed Darawish Basalt, Jordan 


\section{Introduction}

The basalt in Jordan occurs as sporadic volcanic centers along the eastern side of the Dead Sea [1]. The basaltic rocks cover about $18 \%$ of Jordan area [2]. The basalt is associated with continental rifting and in caption of the Dead Sea boundary, and it is found between magmatism and tectonic activities that have produced melted generation into fissure system [3]. The volcanism occurs at the western margin of the Arabian plate and has been tectonically controlled by the Arabian plate movement, which moved northwards along the Dead Sea transform fault. The volcanoes are clearly associated with continental rifting and inception of the Dead Sea plate boundary. The relationship between the magmatism and tectonics of the intraplate volcanism has been reported by [4], indicating that alkaline volcanism in Jordan is similar to the Arabian intraplate volcanic fields, which erupt through two main fissure systems along the eastern margin of the Dead Sea rift in the east-west direction [3] [5]. The volcanism has probably commenced during the Miocene period and continued to the Pleistocene [6]). The eruptions of basaltic flows in Jordan are classified and distributed into four groups; first: Central Jordan Basalt (basalt volcanoes within the rift); second: South Jordan Basalt (the eastern margin basalt) and third: Northeast Jordan basalt, Harrat Al-Sham (plateau basalt) [1], and fourth group is the Northeast basalt (Harrat Irbid) [7]. The volcanic basalts flowing broadly at central and north west Jordan have been found to occur in eight places, namely, Tafila, Wadi Dana, Jabal Shiihan, El-Lajjoun, Jurf Ed Darawish, Ghor Al-Katar, Wadi Zarqa-Main and Ash-Shuna Ash-Shamaliyya in the form of plateau basalts. The flows have been composed of wadi fills or individual volcanic bodies (cones, plugs, and dikes) [8] [9].

The studied area (JDB) is located within the intraplate volcanic field in central Jordan at Jurf Ed Darawish Area. The rock samples study of JDB flows covered the basalt flows into Tell El Qirana area, being $4 \mathrm{~km}$ west of Jurf Ed Darawish village. The main objectives of this study were to evaluate the properties of Jurf Ed Darawish basalt (JDB), as well as to investigate the Mineralogy, Petrology, Geochemistry and Petrogensis of the rock basalt outcrop in the study area.

\section{Geological Setting}

The Jurf Ed Darawish Basalt (JDB) are located about $20 \mathrm{~km}$ Southwest of Al Hisa City, and about $4 \mathrm{~km}$ west of Jurf Ed Darawish Village at $35^{\circ} 45^{\prime} 380^{\prime \prime} \mathrm{E}$ to $35^{\circ} 45^{\prime} 394^{\prime \prime} \mathrm{E}$ and $30^{\circ} 30^{\prime} 398^{\prime \prime} \mathrm{N}$ to $30^{\circ} 30^{\prime} 404^{\prime \prime} \mathrm{N}$ (Figure 1). The JDB covers an area of about $20 \mathrm{Km}^{2}$, with width of about 0.5 to $2 \mathrm{~km}$ which include Tell El Qirana area. The JDB is represented by the volcanoes of central Jordan, within the continental plateau. The basaltic study erupted onto the middle Pleistocene age, second stage of the opining of the Red Sea at last $5 \mathrm{Ma}$ [1] [9]. The JDB is covered with Amman Silicified limestone and Al Hisa Phosphorite within Belqa Group of Campanian age, and covered by fluviatile gravels, cobbles and boulders of basalt and alluvium and wadi sediments [10]. 


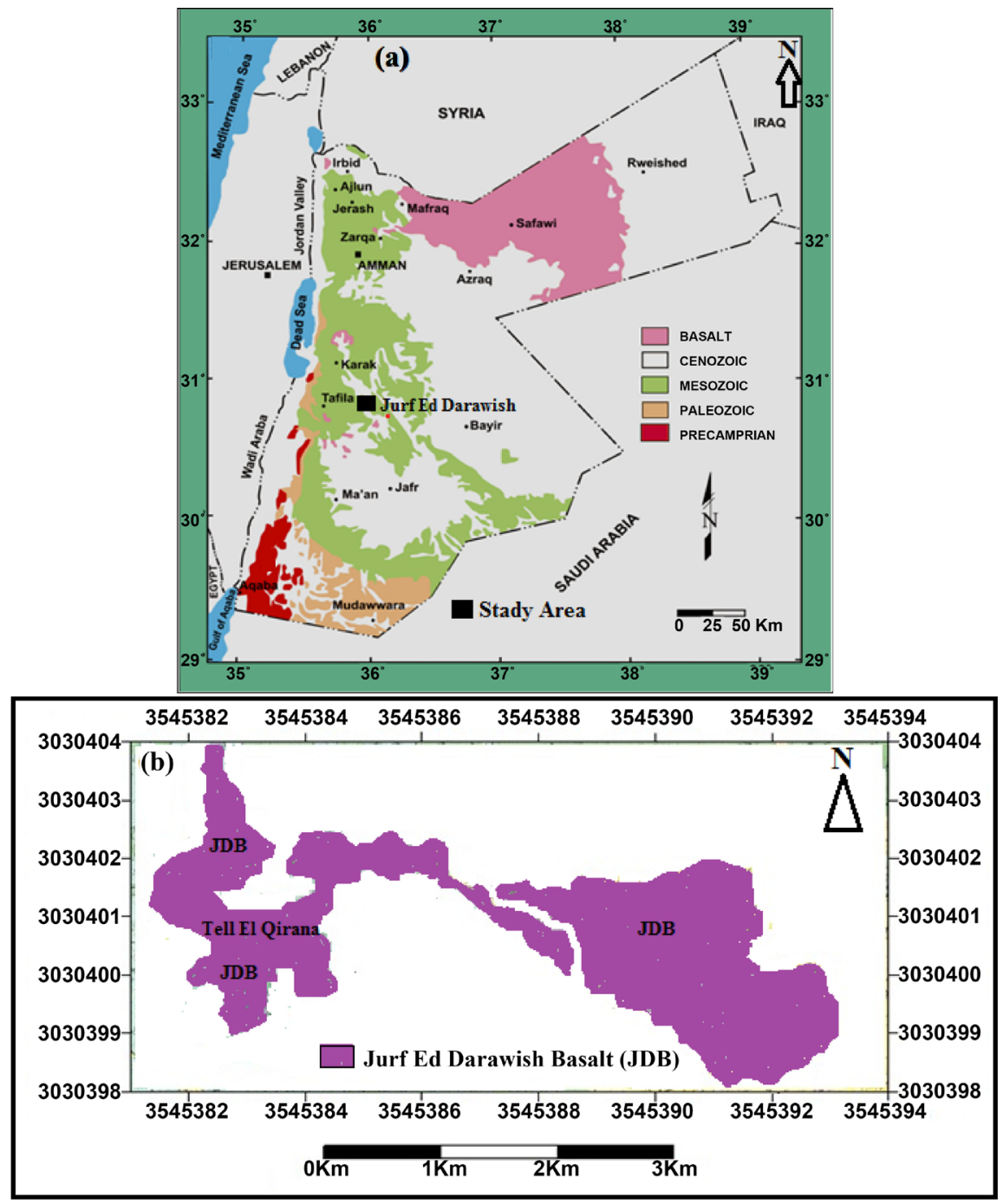

Figure 1. (a) Simplified Geological map of Jordan shows the Study Area (Jurf Ed Darawish Basalt), (b) Study area Jurf Ed Darawish Basalt (JDB), modified after [10].

The study area is affected by Jurf Ed Darawish faults trending NE-SW, and many faults trending NW-SE are distributed in the study area and subparallel to the Al Karak Al Fayha fault system, these fault trending the E-W direction [11].

\section{Sampling and Analytical Techniques}

A total of 16 representative rock chip samples were collected from the outcropping of Jurf Ed Darawish Basalt (JDB) in central Jordan (Figure 1). The samples are crushed and powdered using a stainless steel Jaw Crusher and an Agate Ball Mill machine to obtain a grain size (less than $-80 \mu$ ). The samples were quartered to get a statistically representative (splitter) fraction and powdered using two geochemical techniques at the labs of $\mathrm{Al}$ al-Bayt University. The major elements were analyzed on fused glass discs-like pellet (bead) using a Phillips X-Ray Florescence Spectrometry (XRF) MAGIX PRO PW 2440 Model at the Al al-Bayt University (Water Environment and Arid Region Research Center Labs). 
A total of $2 \mathrm{~g}$ of the powder samples were mixed with $8 \mathrm{~g}$ of lithium tetra borate and fused in platinum crucibles over gas burners $\left(1000^{\circ} \mathrm{C}\right)$ for $1 \mathrm{~h}$. The melts were poured into a mold to create glass disks. The Loss on Ignition (LOI) was determined by the weight lost after melting at $1000^{\circ} \mathrm{C}$. Thereafter trace elements of $\mathrm{Sr}, \mathrm{Cr}, \mathrm{Co}, \mathrm{Ni}, \mathrm{Pb}$ and $\mathrm{Ba}$ analyses by using Atomic Absorption Spectrometry (AAS), and the elements of $\mathrm{Zr}, \mathrm{Rb}, \mathrm{Nb}, \mathrm{Y}$ and Ce analysis by using Inductively Coupled Plasma (ICP) at Al al-Bayt University, Water Environment and Arid Regions Research Center. Digestion 0.2 gm powder samples for Aquaregia solution $(2.5 \mathrm{ml} \mathrm{HCl}+2.5 \mathrm{ml} \mathrm{HNO}+5 \mathrm{ml} \mathrm{HF})$ and added $50 \mathrm{ml}$ of $\mathrm{H}_{3} \mathrm{BO}_{3}$ to produce original solution samples, at Institute of Earth and Environmental Sciences labs, Al al-Bayt University. Thin sections were prepared at Institute of Earth and Environmental Sciences labs, $\mathrm{Al}$ al-Bayt University and petrographically investigated via a polarizing microscope type Lico proccer with different magnifications. The geochemical data were processed and pictorially represented using the softwares programs. Igpet 32 and GCDkit have been used to visualize, elaborate and model the geochemical data for igneous petrography purposes. CIPW-Norm calculations were carried out using the Excel sheet [12].

\section{Results}

\subsection{Petrography and Mineralogy}

The Jurf Ed Darawish Basaltic rock samples study were holocrystalline, hypidiomorphic fine to medium grained and exhibited aphanitic to porphyritic texture, with elongated and oval-shaped vesicles. The JDB basaltic rocks in hand specimen are black to grey in color and fine-grained. The melanocratic rocks typically showed porphyritic and trachytic texture and are characterized by olivine, diopside and plagioclase phenocrysts embedded in a fine-grained groundmass that mainly consists of plagioclase, olivine, diopside and opaque minerals. The average modal composition is 45 vol.\% plagioclase, 25 vol.\% clinopyroxene, (diopside), 20 vol.\% olivine, 10 vol.\% opaque minerals (iron oxide). The secondary minerals included calcite and iddingsite. The common textures of the JDBrock samples were aphanitic, porphyritic, trachytic, glomeroporphyritic, sub ophitic, vesicular, corona and amygdaloidal.

\subsubsection{Plagioclase}

Plagioclase occurs in tow generation, being 3 to $6 \mathrm{~mm}$ long hypidiomorphiclaths and fine crystals in the groundmass. The sub-hedral plagioclase laths have compositions with 33 to 45 vol.\% for modal of the rock, indicating labradorite to bytownite composition. The crystals showed simple twining. The extinction angles on plagioclase phenocrysts ranged from $28^{\circ}$ to $33^{\circ}$. The ternary diagram for plagioclase after [13] shows all the samples presented in labradorite and bytownite field (Figure 2(a)). The plagioclase crystals exhibited orientation within olivine and pyroxene crystals, presenting a trachytic texture (Figure $3(\mathrm{c})$ ). The glomerophyritic texture (plagioclase, pyroxene, and olivine) are enclosed in ground mass and it 


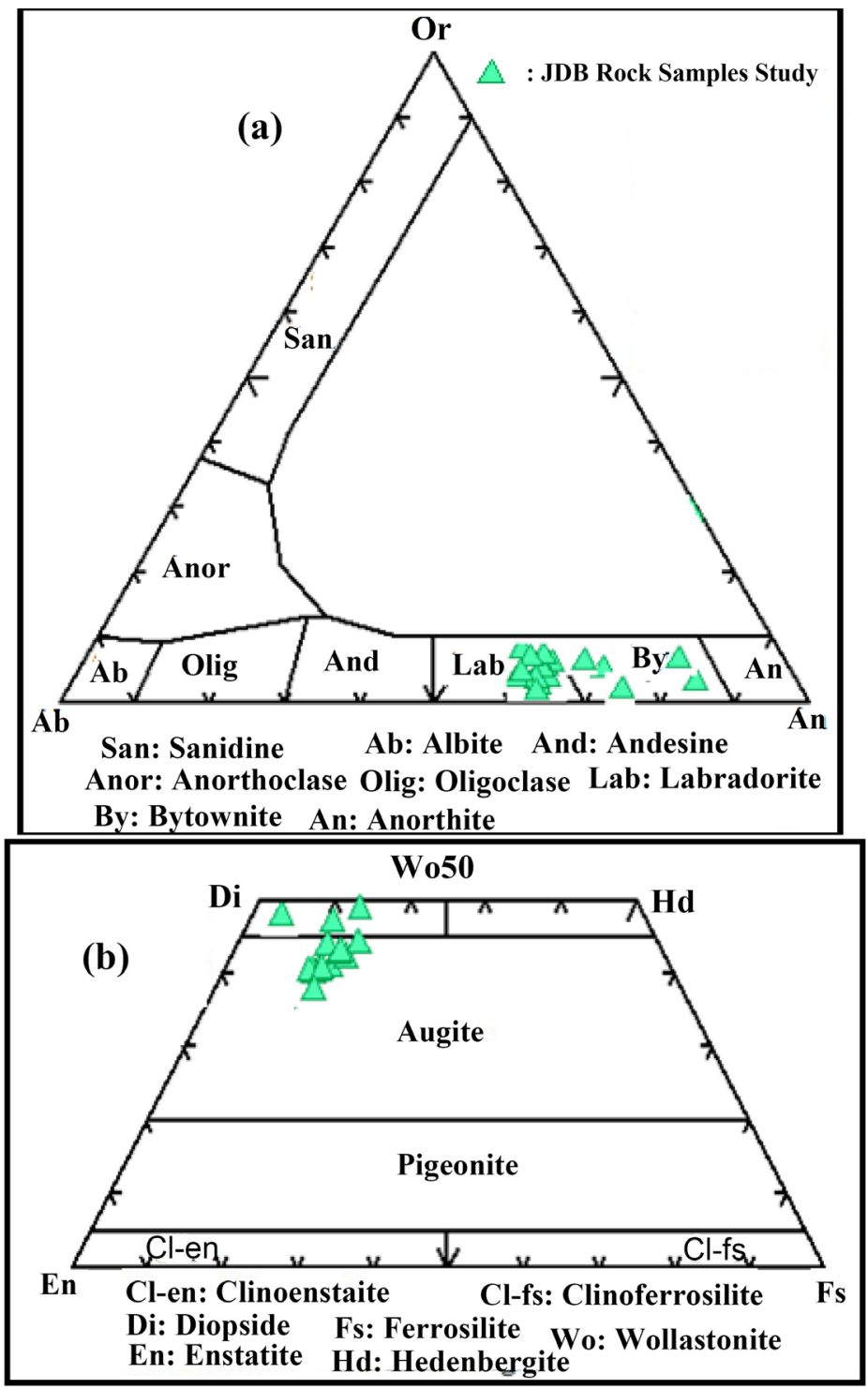

Figure 2. (a) Ab-An-Or ternary for plagioclase of Jurf Ed Darawish basaltic rock samples, modified after [13]. (b) Classification of pyroxene from Jurf Ed Darawish Basaltic rocks after [14], all the sample study plotted within diopside and Augite field.

is divided into clusters of four crystals (Figure 3(e)). Sub ophitic texture are formed for plagioclase crystal partially enclosed by pyroxene crystals. The oscillatory zoning of plagioclase (Figure 3(a) and Figure 3(f)) is present in rock samples study, as a result of the mineral chemistry which continuously oscillates between high and low-temperature compositions going from the core to the rim during crystal growth.

\subsubsection{Pyroxene}

The clinopyroxene (diopside) crystals are colorless or pale brown, 0.5 to $3.5 \mathrm{~mm}$ in length, with subhedral to unhedral crystals, have about 4 to $25 \mathrm{vol}$ \% for modal. Two set cleavage intersected at $\sim 90^{\circ}$ in the cross-section (Figure $3(\mathrm{~b})$ ). The pyroxene crystals have an inclined extinction between $41^{\circ}$ to $47^{\circ}$, indicating the 


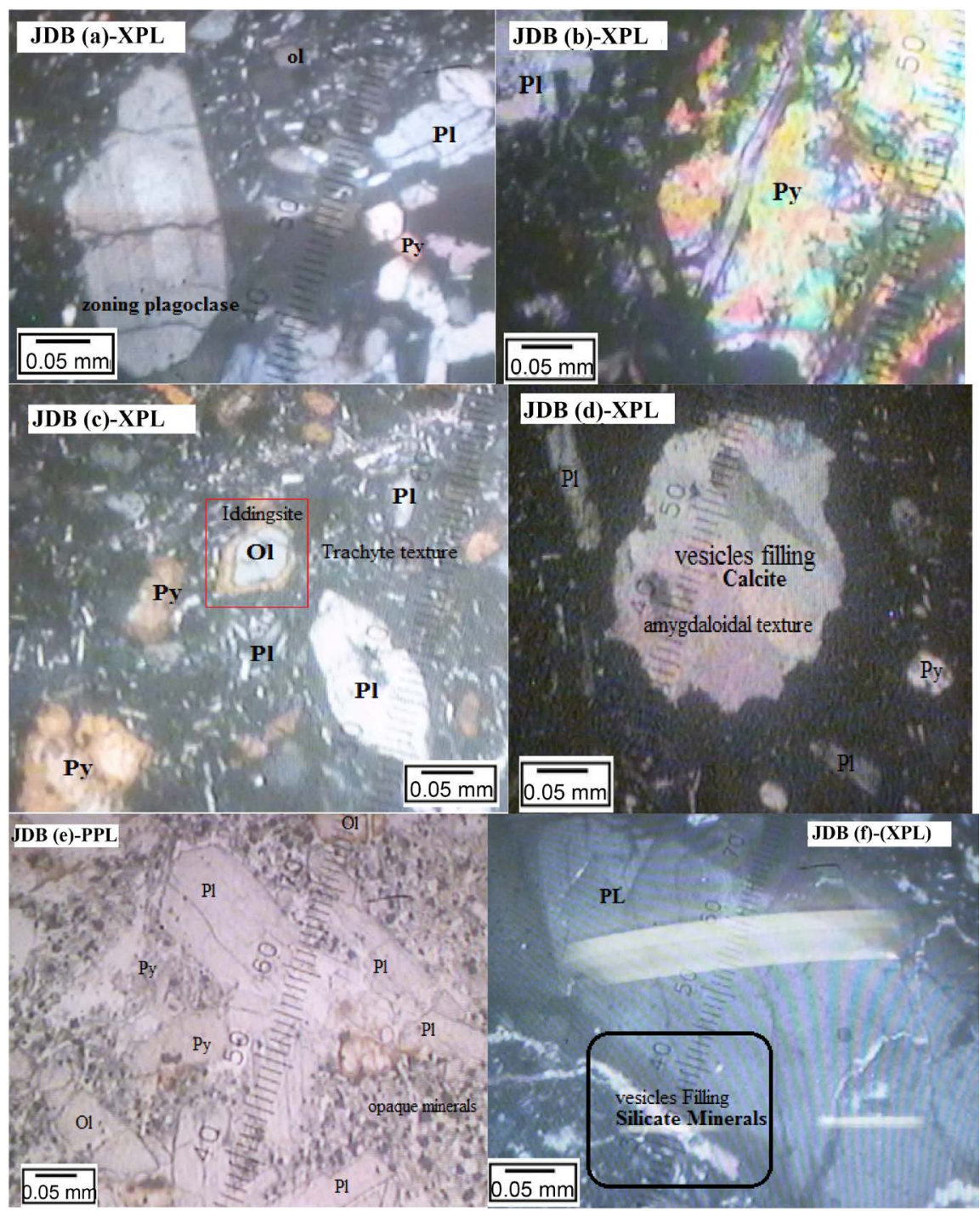

Figure 3. Photomicrographs of the JDB rock samples study (a) Simple twining and zoning of plagioclase, with Intergranular texture minerals (XPL, magnification $4 \times$ ); (b) Clinopyroxene crystal with second order interference color, and plagioclase crystal (XPL, magnification $4 \times$ ); (c) Euhedral to Subhedral olivine crystals, rounded by iron oxide in the rim iddingsite minerals and form to corona texture (XPL, magnification $4 \times$ ); (d) The vesicles were filled with secondary minerals calcite form to amygdaloidal texture (XPL, magnification $4 \times$ ); (e) Glomeroporphyritic texture, plagioclase and olivine crystals has bunched in aggregate, opaque minerals are present (PPL, magnification $4 \times$ ); (f) Euhedral Plagioclase crystal, vesicles filling with silicate minerals (XPL, magnification $4 \times$ ); (Ol: olivine; cpx: clinopyroxene; Pl: plagioclase; magnification $4 \times=0.05 \mathrm{~mm}$ ).

presence of clinopyroxene of diopside to augite mineral. The classification of pyroxene after [14] diagram, the rock samples of JDB is plotted within diopside and augite field (Figure 2(b)), these result documented within [15]. The clinopyroxene intersected with plagioclase crystals to form sub ophitic texture.

\subsubsection{Olivine}

The phenocrysts olivine crystals occuras eubhedral to subhedral crystals, ranging 
between $2 \mathrm{~mm}$ to $5 \mathrm{~mm}$ in diameter in the groundmass and forming 10 vol.\% to 20 vol.\% for modal. The olivine phenocrysts showed high relief with prismatic crystals, cracks and fracture, it is a light to colorless crystal in PPL and parallel extension. The olivine crystals exhibiting high degree of alteration to iddingsite have brownish to red color. The aggregate crystals exhibit glomeroporphyritic texture. The Glomeroporphyritic texture has bunched plagioclase and olivine crystals in aggregate. Iddingsite is common, particularly the edge (rim) of the crystal which produces corona texture (Figure $3(\mathrm{c})$ ). Trachyte texture is formed by the olivine crystal surrounded by plagioclase laths.

\subsubsection{Opaque and Accessory Minerals}

The opaque minerals are found in JDB, forming about 5 vol.\% to 10 vol.\% model of the rocks, and ranging from 0.2 to $2 \mathrm{~mm}$ in size. They mostly occur as iron oxide magnetite and illuminate phenocrysts. The iron oxide is black in color with PPL and XPL optics. The CIPW norm calculation for the iron oxide mineral range between 4.88 to $5.92 \mathrm{wt} \%$ and 1.96 to $2.34 \mathrm{wt} \%$ norm of magnetite $\left(\mathrm{Fe}_{3} \mathrm{O}_{4}\right)$ and ilmenite $\left(\mathrm{FeTiO}_{3}\right)$, respectively. Apatite being the accessory minerals is found in JDB rock sample study with a low percentage.

\subsubsection{Vesicles}

The JDB rock samples show an irregular, rounded to elongated vesicles, weighing from $4 \mathrm{~mm}$ to $6 \mathrm{~mm}$. The vesicles were filled with secondary minerals such as calcite and silicate minerals to produce amygdaloidal texture (Figure 3(d) and Figure 3(f)).

\subsubsection{Groundmass}

The groundmass of rock sample study consists of plagioclase (labradorite and bytownite), pyroxene (diopside, augite), olivine and opaque minerals (mainly iron oxide), with secondary minerals such as iddingsite, calcite, and silicate.

\subsection{Geochemistry}

\subsubsection{Major Oxides}

The results analysis of sixteen JDB rock samples study for major, minor, and trace elements is listed in Table 1. The JDB rocks exhibit a narrow range of silica $\left(\mathrm{SiO}_{2}\right)$ saturation (between 46.11 to $\left.49.69 \mathrm{wt} \%\right)$, with an average of $48.14 \mathrm{wt} \%$, which is within the average value reported by several authors for alkali basalt and basanite [2] [3] [16] [17], and it can be classified as basalt to Trachy basalt and basalt picrite using the Total Alkalis Vs. Silica classification scheme [18] and [19] (Figure 4(a) and Figure 4(b)). The $\mathrm{Zr} / \mathrm{TiO}_{2}$ verses $\mathrm{Nb} / \mathrm{Y}$ diagram after [20], shows all the rock samples study classified by JDB, and plotted within the alkaline basalt (Figure $4(\mathrm{c})$ ). The $\mathrm{Al}_{2} \mathrm{O}_{3}$ contents in the JDB samples vary from 14.11 to $16.74 \mathrm{wt} \%$, within average $15.28 \mathrm{wt} \%$, meanwhile, the concentration of $\mathrm{CaO}$ varies between 7.43 and $9.98 \mathrm{wt} \%$ within an average of $8.94 \mathrm{wt} \%$ (Table 1). The $\mathrm{MgO}$ content of the JDB rock sample ranged from $3.47 \mathrm{wt} \%$ to $8.65 \mathrm{wt} \%$ with an average of $6.68 \mathrm{wt} \%$. The $\mathrm{Mg}$ number $(\mathrm{Mg} \neq)$, defined as the molecular proportion 
Table 1. Chemical analyses of the Rock samples from JDB, major oxides (wt\%), trace elements (ppm) and CIPW wt\% norm.

(a)

\begin{tabular}{|c|c|c|c|c|c|c|c|c|c|}
\hline S. No. & JD1 & JD2 & JD3 & JD4 & JD5 & JD6 & JD7 & JD8 & JD9 \\
\hline $\mathrm{SiO}_{2} \mathrm{wt} \%$ & 49.44 & 48.12 & 47.35 & 48.34 & 49.69 & 48.16 & 48.78 & 48.26 & 48.58 \\
\hline $\mathrm{TiO}_{2}$ & 1.18 & 1.19 & 1.11 & 0.94 & 1.11 & 1.14 & 1.10 & 1.23 & 0.93 \\
\hline $\mathrm{Al}_{2} \mathrm{O}_{3}$ & 15.26 & 15.27 & 16.43 & 15.65 & 14.33 & 16.74 & 14.11 & 15.12 & 14.78 \\
\hline $\mathrm{FeO}$ & 2.95 & 3.48 & 3.63 & 3.21 & 3.48 & 3.21 & 3.71 & 3.21 & 3.63 \\
\hline $\mathrm{Fe}_{2} \mathrm{O}_{3}$ & 8.84 & 10.44 & 10.89 & 9.58 & 10.34 & 9.62 & 11.12 & 9.61 & 10.89 \\
\hline $\mathrm{MnO}$ & 0.14 & 0.15 & 0.13 & 0.13 & 0.15 & 0.14 & 0.14 & 0.14 & 0.13 \\
\hline $\mathrm{MgO}$ & 6.41 & 7.47 & 8.65 & 7.46 & 5.44 & 6.86 & 6.43 & 7.94 & 6.75 \\
\hline $\mathrm{CaO}$ & 9.98 & 8.87 & 7.43 & 8.66 & 9.86 & 9.45 & 8.90 & 9.20 & 8.46 \\
\hline $\mathrm{Na}_{2} \mathrm{O}$ & 2.12 & 1.76 & 1.15 & 2.16 & 2.10 & 1.10 & 2.09 & 2.17 & 1.86 \\
\hline $\mathrm{K}_{2} \mathrm{O}$ & 3.11 & 2.80 & 2.76 & 3.29 & 2.73 & 3.28 & 2.35 & 2.67 & 2.58 \\
\hline $\mathrm{P}_{2} \mathrm{O}_{5}$ & 0.18 & 0.21 & 0.19 & 0.20 & 0.22 & 0.21 & 0.21 & 0.25 & 0.22 \\
\hline Sum & 99.61 & 99.76 & 99.72 & 99.62 & 99.45 & 99.91 & 98.94 & 99.80 & 98.81 \\
\hline LOI & 0.39 & 0.24 & 0.28 & 0.38 & 0.44 & 0.09 & 1.06 & 0.20 & 1.19 \\
\hline $\mathrm{Mg} \#$ & 49.90 & 49.50 & 52.10 & 51.60 & 41.90 & 49.50 & 44.20 & 53.10 & 45.90 \\
\hline \multicolumn{10}{|c|}{ Trace Elements (ppm) } \\
\hline $\mathrm{Sr}$ & 453 & 523 & 387 & 368 & 386 & 441 & 630 & 432 & 386 \\
\hline $\mathrm{Zr}$ & 87 & 110 & 94 & 75 & 83 & 76 & 136 & 93 & 74 \\
\hline $\mathrm{Cr}$ & 23.10 & 42.80 & 62.70 & 87.40 & 77.00 & 78.10 & 88.70 & 186.80 & 196.20 \\
\hline Co & 11.80 & 12.50 & 17.50 & 17.70 & 15.00 & 14.20 & 13.90 & 14.90 & 18.50 \\
\hline $\mathrm{Ni}$ & 13.21 & 14.32 & 15.70 & 17.70 & 15.00 & 14.20 & 13.90 & 14.90 & 18.50 \\
\hline $\mathrm{Pb}$ & 10.40 & 3.30 & 6.30 & 15.30 & 6.20 & 13.90 & 6.10 & 7.40 & 4.30 \\
\hline $\mathrm{Ba}$ & 135 & 118 & 185 & 147 & 87 & 92 & 118 & 164 & 214 \\
\hline $\mathrm{Rb}$ & 9 & 11 & 13 & 15 & 10 & 12 & 16 & 11 & 12 \\
\hline $\mathrm{Nb}$ & 23 & 27 & 21 & 42 & 19 & 23 & 25 & 19 & 22 \\
\hline $\mathrm{Y}$ & 15 & 23 & 19 & 25 & 17 & 20 & 17 & 16 & 19 \\
\hline $\mathrm{Ce}$ & 42 & 67 & 59 & 46 & 62 & 44 & 46 & 37 & 28 \\
\hline \multicolumn{10}{|c|}{ CIPW Norms } \\
\hline Or & 18.44 & 16.61 & 16.37 & 19.51 & 19.44 & 19.38 & 14.06 & 15.84 & 15.42 \\
\hline $\mathrm{Ab}$ & 16.83 & 14.89 & 9.73 & 14.97 & 17.5 & 9.31 & 17.85 & 17.54 & 15.91 \\
\hline An & 23.03 & 25.57 & 31.62 & 23.38 & 19.95 & 31.11 & 22.41 & 23.38 & 24.67 \\
\hline $\mathrm{Pl}$ & 39.86 & 40.47 & 41.35 & 38.35 & 37.46 & 40.41 & 40.26 & 41.23 & 40.58 \\
\hline $\mathrm{Di}$ & 21.05 & 14.76 & 3.49 & 15.21 & 23.06 & 11.99 & 17.43 & 16.82 & 13.64 \\
\hline Hy & - & 6.17 & 19.15 & 5.81 & - & 10.82 & 11.05 & - & 13.3 \\
\hline Ap & 0.42 & 0.49 & 0.44 & 0.46 & 0.43 & 0.49 & 0.49 & 0.58 & 0.51 \\
\hline $\mathrm{Ma}$ & 4.29 & 5.06 & 5.28 & 4.67 & 5.05 & 0 & 5.44 & 4.67 & 5.32 \\
\hline Il & 2.24 & 2.26 & 2.11 & 1.79 & 2.11 & 2.17 & 2.11 & 2.34 & 1.79 \\
\hline $\mathrm{Ol}$ & 13.08 & 14.76 & 11.82 & 18.19 & 12.28 & 10.1 & 9.19 & 18.11 & 9.44 \\
\hline $\mathrm{Ne}$ & 0.65 & - & - & 1.84 & 0.14 & - & 0.44 & - & - \\
\hline
\end{tabular}


(b)

\begin{tabular}{|c|c|c|c|c|c|c|c|}
\hline wt\% & JD10 & JD11 & JD12 & JD13 & JD14 & JD15 & JD16 \\
\hline $\mathrm{SiO}_{2}$ & 47.13 & 48.12 & 47.13 & 48.29 & 46.11 & 48.55 & 48.12 \\
\hline $\mathrm{TiO}_{2}$ & 0.71 & 1.16 & 0.67 & 0.79 & 1.18 & 1.10 & 0.91 \\
\hline $\mathrm{Al}_{2} \mathrm{O}_{3}$ & 15.13 & 14.18 & 16.21 & 15.73 & 15.48 & 14.86 & 15.21 \\
\hline $\mathrm{FeO}$ & 4.06 & 3.72 & 3.94 & 3.67 & 3.53 & 3.69 & 3.55 \\
\hline $\mathrm{Fe}_{2} \mathrm{O}_{3}$ & 12.17 & 11.15 & 11.83 & 11.09 & 10.59 & 11.07 & 10.66 \\
\hline $\mathrm{MnO}$ & 0.14 & 0.13 & 0.13 & 0.13 & 0.14 & 0.14 & 0.12 \\
\hline $\mathrm{MgO}$ & 6.48 & 6.51 & 5.62 & 3.47 & 7.35 & 6.43 & 7.57 \\
\hline $\mathrm{CaO}$ & 8.93 & 8.91 & 8.61 & 9.83 & 8.93 & 8.94 & 8.10 \\
\hline $\mathrm{Na}_{2} \mathrm{O}$ & 2.10 & 1.87 & 2.35 & 2.36 & 2.10 & 1.32 & 2.11 \\
\hline $\mathrm{K} 2 \mathrm{O}$ & 2.53 & 3.05 & 2.60 & 2.47 & 3.12 & 3.23 & 2.54 \\
\hline $\mathrm{P}_{2} \mathrm{O}_{5}$ & 0.23 & 0.23 & 0.22 & 0.45 & 0.23 & 0.18 & 0.19 \\
\hline Sum & 99.61 & 99.03 & 99.31 & 98.28 & 98.76 & 99.51 & 99.08 \\
\hline LOI & 0.39 & 0.97 & 0.69 & 1.72 & 1.24 & 0.49 & 0.92 \\
\hline Mg\# & 42.20 & 44.40 & 39.50 & 30.10 & 48.80 & 44.30 & 49.40 \\
\hline \multicolumn{8}{|c|}{ Trace Elements (ppm) } \\
\hline $\mathrm{Sr}$ & 386 & 380 & 418 & 367 & 365 & 492 & 386 \\
\hline $\mathrm{Zr}$ & 83 & 93 & 86 & 102 & 94 & 79 & 103 \\
\hline $\mathrm{Cr}$ & 146.00 & 154.40 & 208.10 & 182.40 & 170.00 & 196.80 & 221.35 \\
\hline Co & 15.50 & 15.40 & 16.40 & 18.50 & 17.70 & 14.50 & 16.60 \\
\hline $\mathrm{Ni}$ & 15.50 & 15.40 & 16.40 & 17.50 & 17.70 & 14.50 & 16.60 \\
\hline $\mathrm{Pb}$ & 3.90 & 7.80 & 3.00 & 27.80 & 3.70 & 6.60 & 2.90 \\
\hline $\mathrm{Ba}$ & 84 & 167 & 86 & 64 & 48 & 45 & 68 \\
\hline $\mathrm{Rb}$ & 14 & 9 & 11 & 13 & 15 & 9 & 8 \\
\hline $\mathrm{Nb}$ & 23 & 17 & 16 & 19 & 23 & 16 & 17 \\
\hline $\mathrm{Y}$ & 20 & 18 & 19 & 16 & 19 & 17 & 21 \\
\hline $\mathrm{Ce}$ & 36 & 31 & 33 & 28 & 42 & 47 & 37 \\
\hline \multicolumn{8}{|c|}{ CIPW Norms } \\
\hline Or & 15.17 & 18.2 & 15.48 & 14.83 & 18.72 & 19.21 & 15.13 \\
\hline $\mathrm{Ab}$ & 17.24 & 15.99 & 17.97 & 20.31 & 10.54 & 11.25 & 18.1 \\
\hline An & 24.47 & 21.5 & 26.15 & 25.49 & 23.86 & 25.17 & 24.76 \\
\hline $\mathrm{Pl}$ & 41.71 & 37.43 & 44.12 & 45.81 & 34.41 & 36.42 & 42.78 \\
\hline Di & 15.47 & 18.62 & 12.98 & 17.94 & 16.11 & 12.79 & 12.1 \\
\hline Hy & - & 3.58 & - & 5.06 & - & 12.79 & 6.31 \\
\hline Ap & 0.53 & 0.52 & 0.51 & 1.07 & 0.53 & 0.42 & 0.44 \\
\hline $\mathrm{Ma}$ & 5.92 & 5.45 & 5.76 & 5.41 & 5.18 & 5.38 & 5.19 \\
\hline Il & 1.35 & 2.22 & 1.27 & 1.52 & 2.26 & 2.11 & 1.75 \\
\hline $\mathrm{Ol}$ & 19.49 & 14.52 & 18.75 & 8.35 & 18.77 & 8.48 & 16.3 \\
\hline $\mathrm{Ne}$ & 0.33 & - & 1.13 & - & 4.05 & - & - \\
\hline
\end{tabular}

Or: Orthoclase, Ab: Albite, An: Anorthite, Pl: Plagioclase, Di: Diopside, Hy: Hypersthene, Ap: Apatite, He: Hematite, IL Ilmenite, Ol: Olivine, Ne: Nepheline. 

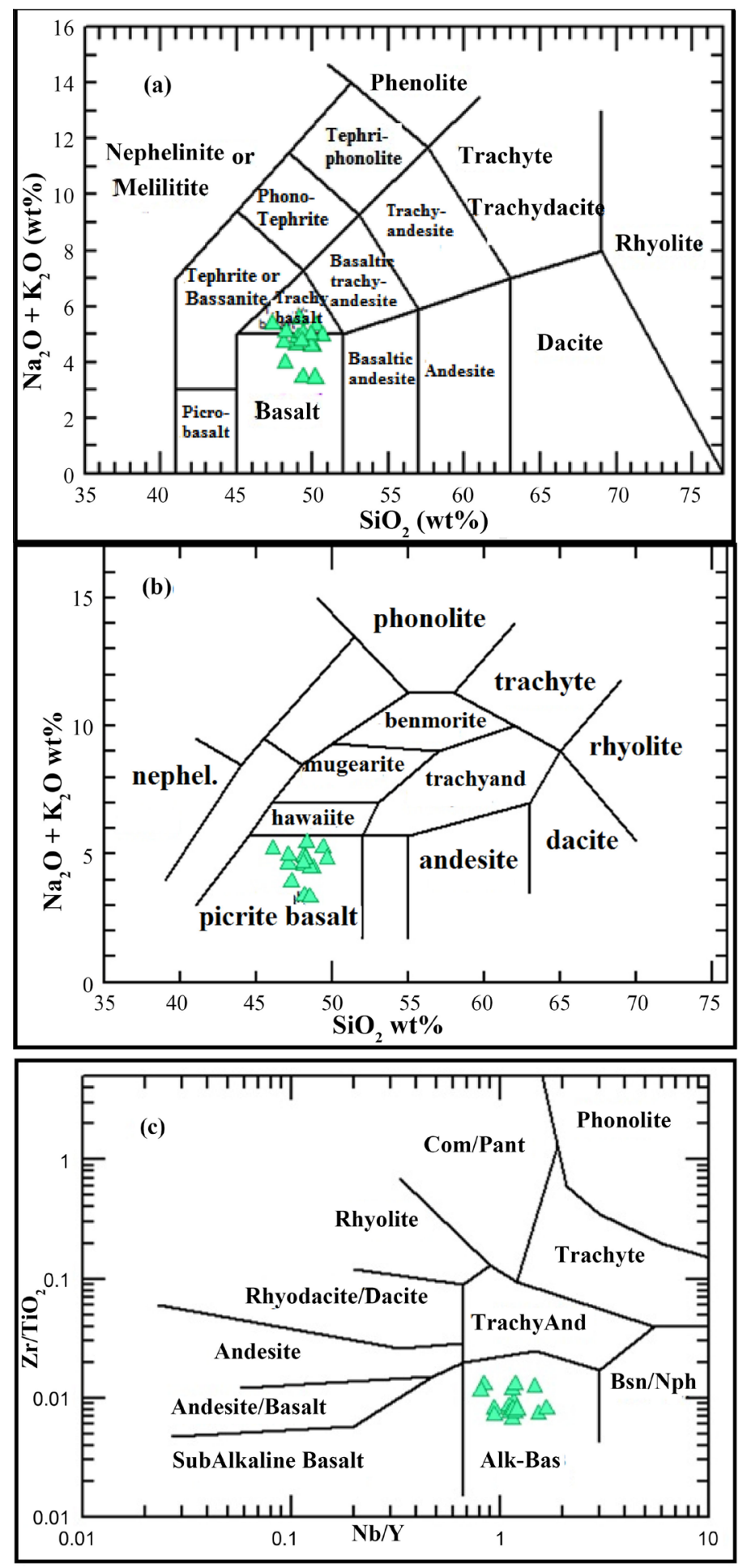

Figure 4. (a) $\mathrm{SiO}_{2}$ vs. $\left(\mathrm{Na}_{2} \mathrm{O}+\mathrm{K}_{2} \mathrm{O}\right)$ (TAS) diagram after [29], the JDB rock samples plotted within basalt to Trachy basalt Field]; (b) $\mathrm{SiO}_{2}$ vs. $\left(\mathrm{Na}_{2} \mathrm{O}+\mathrm{K}_{2} \mathrm{O}\right)$ diagram after [19], the JDB rock samples plotted within basalt picrite filed; (c): $\mathrm{Zr} / \mathrm{TiO}_{2} \mathrm{vs.} \mathrm{Nb} / \mathrm{Y}$ diagram after [20], the JDB rock samples plotted within Alk-Basalt field,

of $\left(\mathrm{Mg}^{+2} /\left(\mathrm{Mg}^{+2}+\right.\right.$ Total $\left.\mathrm{Fe}\right)$ [21]. $\mathrm{Mg} \#$ was used as a petrogenetic indicator for magma fractionation and its primitive volcanic rocks [22]. The JDB exhibited a 
high $\mathrm{Mg} \neq$ ranging between 30 to 53, with an average of 46 . The Mg\# of the indicated JDB evolved within moderately basalt. The relationship between Mg\# and $\mathrm{SiO}_{2}$ shows a decrease in $\mathrm{Mg \#}$ with increasing concentration $\mathrm{SiO}_{2}$ (Figure 5(a)). These relationship tend to be that fractional crystallization probably plays a role in decreasing $\mathrm{Mg}$-number as a function of increasing $\mathrm{SiO}_{2}$ [23]. The magnesium value was considered for Fe content in the rocks. [24] reported that the values of $\mathrm{Mg} \neq>70$ can be considered as a threshold that characterizes primitive magmas. The total $\mathrm{FeO}$ and $\mathrm{Fe}_{2} \mathrm{O}_{3}$ content of the JDB ranged between $11.79 \mathrm{wt} \%$ to 16.23 $\mathrm{wt} \%$, with an average of $14.16 \mathrm{wt} \%$, indicating that the rocks were enriched in $\mathrm{Fe}$. According to [3], the $\mathrm{SiO}_{2}$ under saturated magma had a high $\mathrm{FeO}$ and $\mathrm{MgO}$ content more than $11 \mathrm{wt} \%$ and $7 \mathrm{wt} \%$, respectively. The content of $\mathrm{Na}_{2} \mathrm{O}$ and $\mathrm{K}_{2} \mathrm{O}$ for the JDB sample study ranged between $1.10 \mathrm{wt} \%$ to $2.36 \mathrm{wt} \%$, and 2.35 $\mathrm{wt} \%$ to $3.29 \mathrm{wt} \%$, respectively. The total alkali $\left(\mathrm{Na}_{2} \mathrm{O}+\mathrm{K} 2 \mathrm{O}\right)$ ranged between $3.45 \mathrm{wt} \%$ to $5.65 \mathrm{wt} \%$, with an average of $4.74 \mathrm{wt} \%$. $\mathrm{The}^{\mathrm{SiO}} \mathrm{O}_{2} \mathrm{Vs}$. Alkalis shows the rock samples study for JDB plotting in the alkaline field, these result indicates that JDB has alkaline rocks (Figure 5(b)). These results have been documented by many authors such as [17] [25] [26] [27] [28]. The major elements

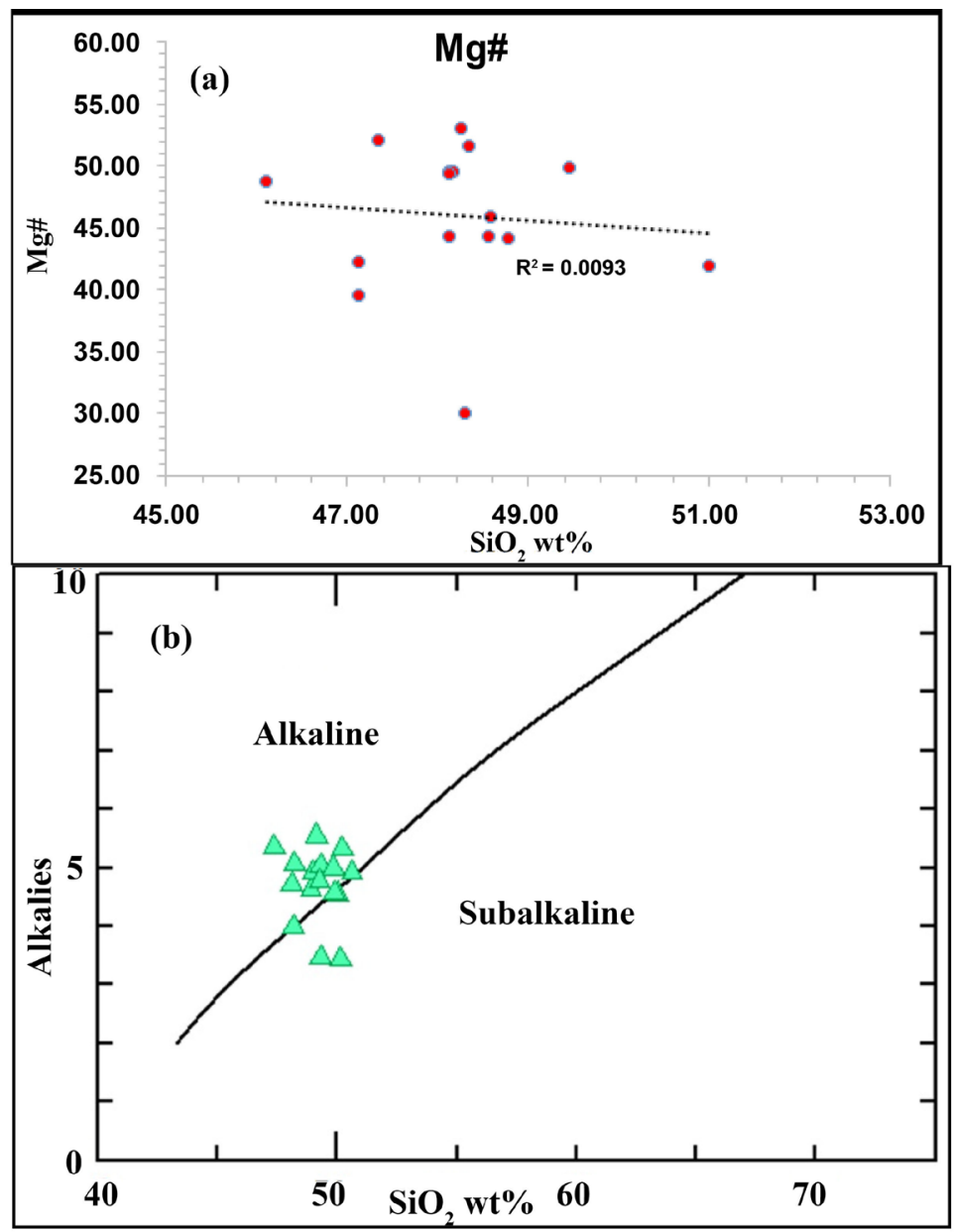

Figure 5. (a) $\mathrm{SiO}_{2}$ vs $\mathrm{Mg} \#$ data, (b) $\mathrm{SiO}_{2}$ Vs. Alkalis After [18], the basalt rock samples (JDB) plotted within Alkaline basalt field. 
concentrations were used to calculate the CIPW norm (Table 1). The Normative anorthite has higher concentrations than albite, which indicates the plagioclase calc alkali nature of these rocks. Apatite and nepheline are present at low percentage with an average of 0.52 and 0.54 , respectively, in the rock samples study (JDB). The high Normative diopside and Hypersthene fall within average of 15.22 and 5.88 respectively, these mean and indicate the clinopyroxene nature of the JDB. The normative of magnetite and ilmenite are present in the JDB, these reflected in the high percentage of the opaque minerals (Figure 3(e)).

\subsubsection{Trace Elements}

The JDB basaltic rock samples have a high content of Cr, Co and Ni. The content of Crrange between 23 to $221 \mathrm{ppm}$ with an average of $132 \mathrm{ppm}$, Co range between 11.20 to 18.50 with an average of $15.48 \mathrm{ppm}$, and Ni ranged between 13.9 to $51.3 \mathrm{ppm}$ within average $20.13 \mathrm{ppm}$ (Table 1). The high content of $\mathrm{Cr}$, $\mathrm{Ni}$ and $\mathrm{Co}$ indicated by the parental magma had been derived through partial melting of peridotite mantle source, which suggests the presence of olivine and clinopyroxene fractions in the JDB [3] [17] [24] [30]. The binary diagram in Figure 6, shows the Mg\# versus $\mathrm{Cr}$, Co and Ni. The general trend of Crdecrease with increasing Mg\# (Figure 6(a)), this result is documented with Zarqa-Ma'in basalt, Ar-Rabba Basalt, Mudawwara-Quwayra Basaltic Dike and Atarous Basalt [17] [25] [26] [31]. Inverstrend falls between Mg\# versus Co and Ni (Figure 6(b) and Figure $6(\mathrm{c})$ ), These results arethe most probable from magma mixing and assimilation within the country rock and this resulted to dilution of $\mathrm{Cr}, \mathrm{Co}$ and $\mathrm{Ni}$, where $\mathrm{Cr}$ is related to clinopyroxene [32].

The concentration of $\mathrm{Sr}, \mathrm{Zr}, \mathrm{Pb}$ and $\mathrm{Ba}$ in the JDB rock sample study had relatively high contents. The Sr ranging between 365 to $630 \mathrm{ppm}$ with average of 425 $\mathrm{ppm}, \mathrm{Zr}$ content 74 to $136 \mathrm{ppm}$ with average of $91 \mathrm{ppm}, \mathrm{Pb}$ range between 2.9 to 27 with average of $8 \mathrm{ppm}$ and Ba range between 45 to 214 within average 114 ppm, respectively (Table 1 ). The $\mathrm{Sr}^{+2}$ is substitute for $\mathrm{Ca}$ in plagioclase minerals (Anorthite $\mathrm{CaAl}_{2} \mathrm{Si}_{2} \mathrm{O}_{8}$ ) and lesser extent was found in $\mathrm{K}$-feldspar. $\mathrm{Zr}$ is found in accessory minerals such as Zirconium $\left(\mathrm{ZrSiO}_{4}\right), \mathrm{Pb}$ substitute for $\mathrm{K}$ in $\mathrm{K}$-feldspar and $\mathrm{Ba}^{+2}$ appears in biotite and potash feldspar, because of its higher charge $\mathrm{Ba}^{+2}$ should be captured by potassium compounds. $\mathrm{Pb}$ tends to be captured by potassium minerals [33] [34].

The Rare Earth Elements (REE) includes Nb, Y, Ce content ranging between 16 to $42 \mathrm{ppm}$ for $\mathrm{Nb}, 15$ to $25 \mathrm{ppm}$ for $\mathrm{Y}$ and 28 to $67 \mathrm{ppm}$ for Ce, respectively (Table 1). The REE were replacement of $\mathrm{Ca}^{+2}$ in accessory minerals such as Apatite $\left(\mathrm{Ca}_{5}\left(\mathrm{PO}_{4}\right)(\mathrm{OH}, \mathrm{F}, \mathrm{Cl})\right.$ and Titanite $\left(\mathrm{CaTiSiO}_{5}\right)$. Niobium $\left(\mathrm{Nb}^{5+}\right)$ does not substitute for major elements because of its high charge, but it may substitute for titanium due to their similar ionic radii and valence state [34]). Ce evidently remains in the liquid at late stage of crystallization, it is concentrated in micas and potash feldspar to produce pollucite minerals $\left(\mathrm{CeAlSi}_{2} \mathrm{O}_{6}\right)$ [35]. The average ratio between $\mathrm{Zr} / \mathrm{Nb}, \mathrm{Y} / \mathrm{Nb}$ and $\mathrm{Zr} / \mathrm{Y}$ are $4.40,0.89$ and 4.98 , respectively. These ratios were documented and reported by [26] [36]) for the intercontinental alkali basalt. 

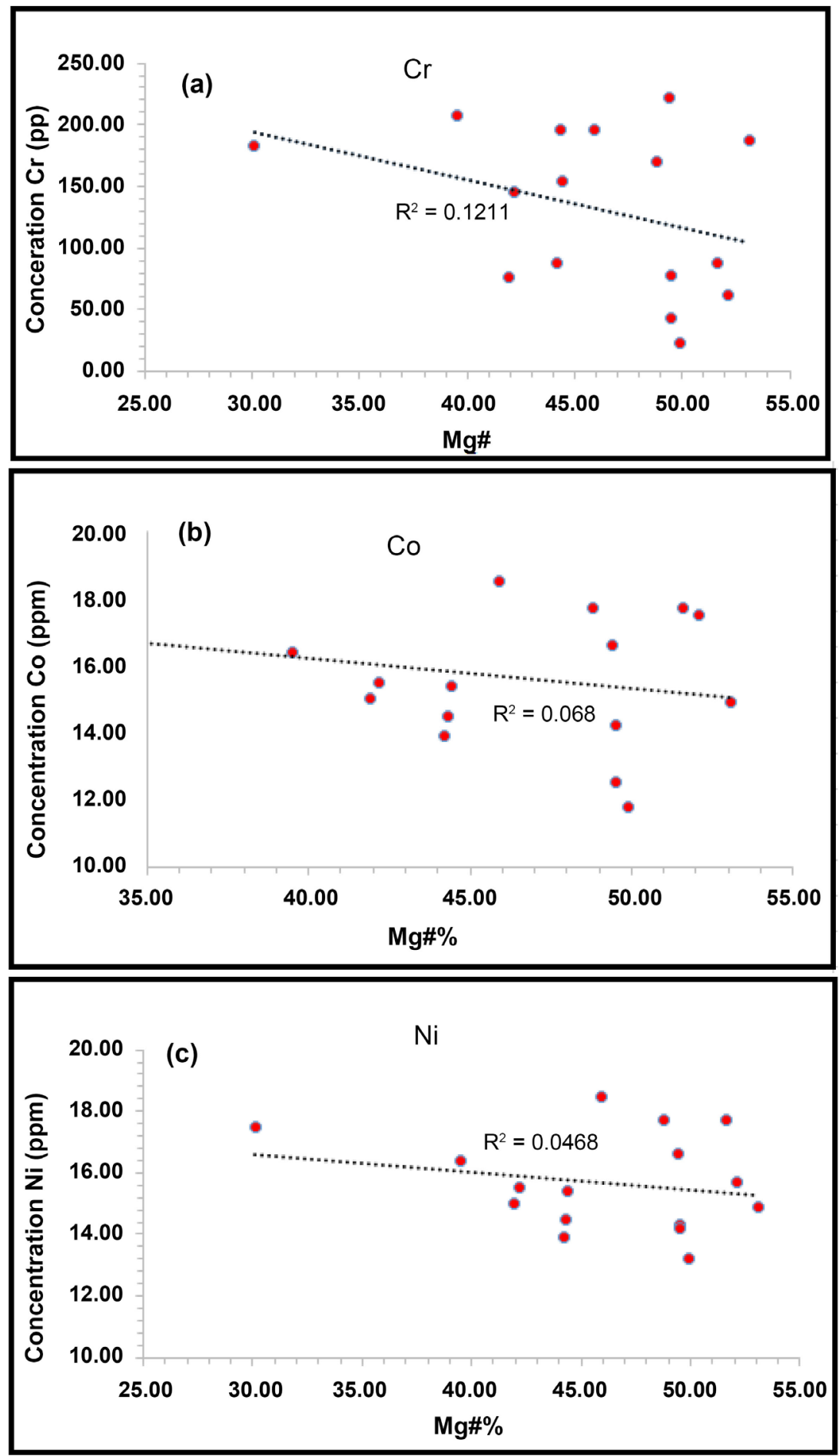

Figure 6. (a) Mg\# vs. Cr data for JDB rock samples study; (b) Mg\# vs. Co data for JDB; (c) Mg\# Vs. Ni data for JDB.

\section{Petrogensis}

The chemical analysis of major and trace elements for JDB rock samples study are used to construct discriminatory diagrams, which help in the classification, nomenclature and interpretation of the tectonic setting of the JDB. The Classifi- 
cation for [37] include all the JDB samples plotted in the alkaline to sub alkaline rock field (Figure 5(b)). The AFM diagram shows the JDBrock samples plotted within the calcalkaline series (Figure $7(a)$ ). The ternary diagrams for Ti-Zr-Sr and Ti-Zr-Y diagrams (Figure 7 (b) and Figure $7(\mathrm{c})$ ) after [32], shows all the JDB Rock samples plotted within the calcalkaline basalt field. The $\mathrm{MgO}-\mathrm{FeO}$ (tot) $-\mathrm{Al}_{2} \mathrm{O}_{3}$ diagram after [38], shows the JDB rock samples were plotted within continental basaltic field (Figure $7(\mathrm{~d})$ ).

The low content of $\mathrm{SiO}_{2}$ (46.11 to $49.69 \mathrm{wt} \%$ ) and high content of $\mathrm{MgO}$ (3.47 to $8.65 \mathrm{wt} \%)$ and total $\mathrm{FeO}+\mathrm{Fe}_{2} \mathrm{O}_{3}(11.79-16.23 \mathrm{wt} \%)$ indicated the natural fractionation of the JDB [17]). The high concentration of Crranging between 23 to $221 \mathrm{ppm}$ within average $132 \mathrm{ppm}$ is consistent with findings reported for primary magma [3] [21] [31] [39]. The high Mg\# (average 46) for JDB is similar to that reported for rock affected by fractionation or accumulation of clinopyroxene, orthopyroxene, as well as olivine and plagioclase [40].

The high content of $\mathrm{Zr} / \mathrm{Y}$ (average 4.98) and $\mathrm{TiO}_{2} / \mathrm{Y}$ (average 0.06) ratios and low content of Y (average $18.81 \mathrm{ppm}$ ) indicate the garnet-bearing source rocks [41]. The spider diagrams for Rock Primordial mantle are used to study basaltic rock samples (JDB) (Figure 8). They presented enrichment of the incompatible

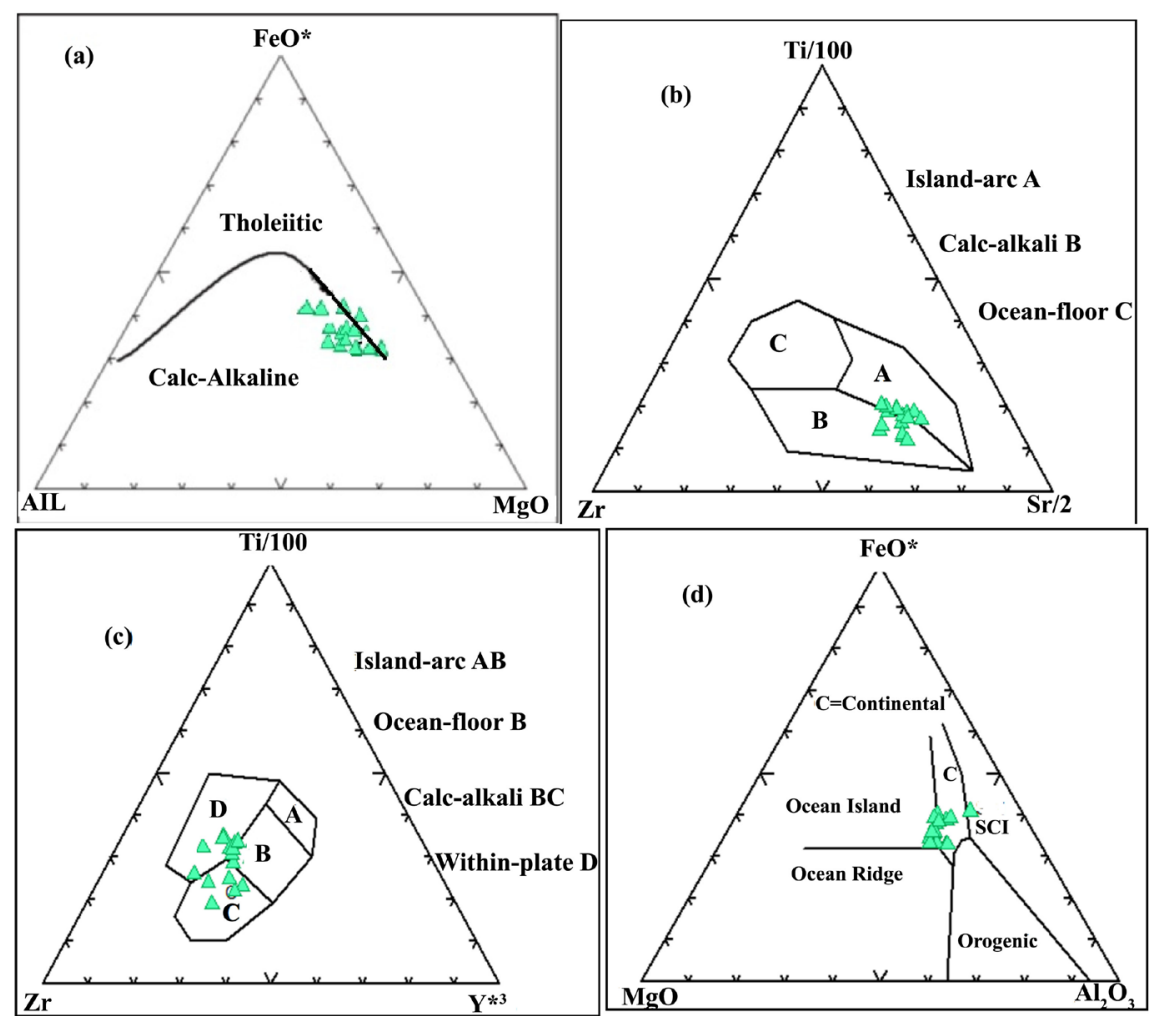

Figure 7. (a) AFM diagram after [37]), shows the basalt rock samples study (JDB) were located within Calc-Alkaline basalt field; (b) Ti-Zr-Sr discrimination diagram after [38], shows the JDB rock samples study were plotted within Calc-alkali basalt field; (c) Ti-Zr-Y discrimination diagram after [32]); shows the basalt rock samples study located within Calc-alkali basalt and Within-Plate basalt field; (d) Discrimination diagram MgO-FeO(tot) $-\mathrm{Al}_{2} \mathrm{O}_{3}$ after [38], shows the JDB rock samples plotted within Continental basaltic field. 


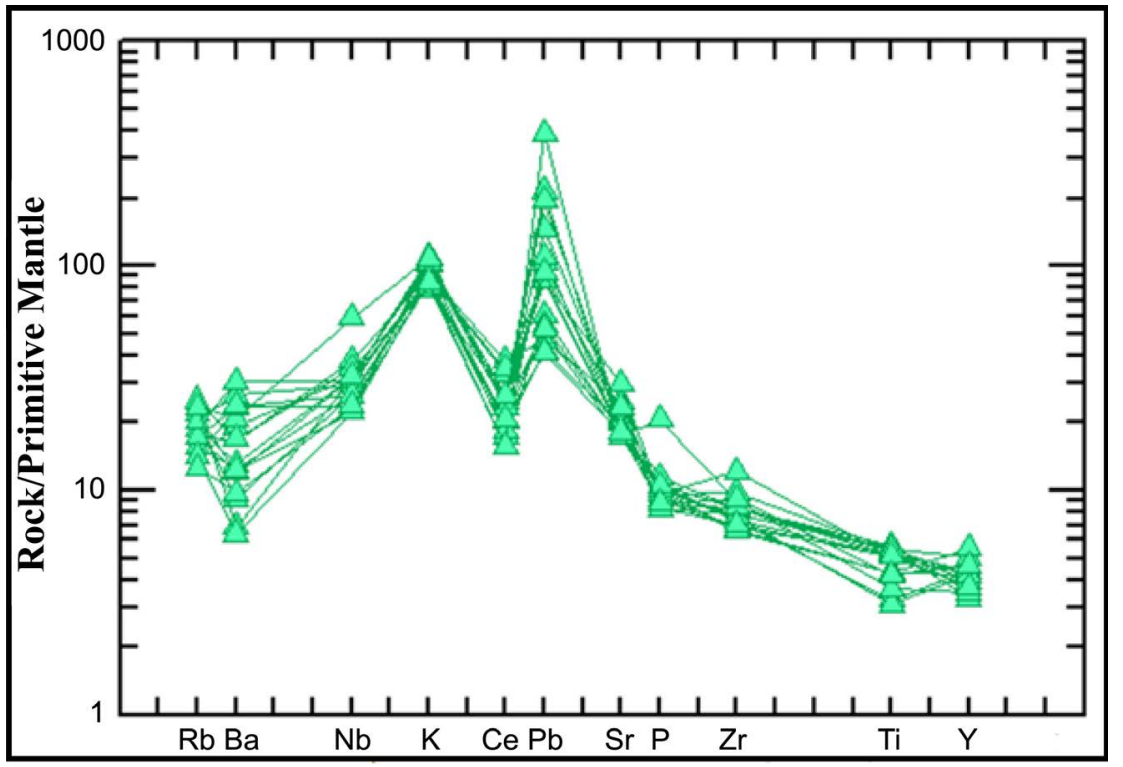

Figure 8. Spider diagram of incompatibility elements from the JDB rock samples study; Rock/Primordial mantle for trace element abundance patterns of the basaltic rocks after [57].

LILE such as $\mathrm{Ba}$ and $\mathrm{K}$, depletion of Ce relative to $\mathrm{K}$, and enrichment of $\mathrm{Nb}$ and $\mathrm{Pb}$ with depletion of $\mathrm{Y}$. The mafic volcanic rocks for JDB exhibited positive $\mathrm{Nb}$, $\mathrm{Zr}$ and $\mathrm{Ti}$ anomalies. The negative anomalies of $\mathrm{Ba}, \mathrm{Sr}, \mathrm{Ti}$ and $\mathrm{P}$ may be attributed to the fractionation of feldspar for $\mathrm{Ba}$ and $\mathrm{Sr}$ depletion apatite for $\mathrm{P}$ depletion, and (Fe-Ti) oxides for Ti depletion [42]. The Rock Primordial mantle value of the basaltic rock samples study (JDB), shows a positive $\mathrm{Nb}$ peak, which conforms to the tertiary to recent continental alkali basalt provinces [16] [17] [43] [44], and indicate the JDB product for the lithosphere from upwelling of the asthenosphere mantle [22] [45] [46].

\section{Discussion}

The basalt samples study (JDB) characterized are alkaline to sub-alkaline with respect to silica content and under saturated $\mathrm{SiO}_{2}$. Similar rock compositions were reported by [25] [26] [27] [39] [45] [47] [48], from central, Northwest and Northeast Jordan. The lithosphere mantle in Arabia within Jordan is chemically heterogeneous [17]. According to [49], there is a possibility that the volcanic rock was sourced from the lower lithosphere depth and from asthenosphere. The Cenozoic interpalate volcanic fields which form Arabia may be the product for the melting of upper mantle wedge material, fertilized during Pan-African subduction and incorporated into the Arabian Lithospheric mantle [3] [46] [49].

According to [50] the primary alkali basalt rocks can be formed by low degree of melting at a pressure as low as $13 \mathrm{kbar}$ and can fractionate to tholeiitic liquids between 4 and $12 \mathrm{kbar}$. [51] explained that the alkali basalt melts can be derived for the low-velocity zonation, 5\% partial melting approximate depths, $85-95 \mathrm{~km}$ within $30 \mathrm{kbar}$ and $10 \%$ partial melting in the Lithosphere, at $60-90 \mathrm{~km}$ within 
19 - $27 \mathrm{kbar}$. The geochemistry of alkaline basalt indicates a source for intraplate volcanism [49]. The basalt flows may be both direct products of mantle partial melting and the differentiates of more primitive picritic partial melts [24]; However, the basalt samples study was plotted within basaltic picrite field (Figure 4(d)).

The $\mathrm{Mg} \#$ values $\left(\mathrm{Mg}^{+2} /\left(\mathrm{Mg}^{+2}+\right.\right.$ Total $\left.\mathrm{Fe}\right)$ ranging from 30 to 53 (Table 1), could bea pointer to the little fractional crystallization and removal of olivine and pyroxene. The concentration of $\mathrm{Cr}$ and $\mathrm{Ni}$ vary between 23 to $221 \mathrm{ppm}$ and 14 to $51 \mathrm{ppm}$, respectively. These concentrations contribute to some degree of olivine fractionation, and tends to increase the incompatible trace element concentration in the studied basalts (JDB) [17]. [48] studied the basalt of Al-Qiranha volcano in central Jordan, and it was concluded that the basalt flows is indicative of a primitive upper mantle that has suffered partial melting at a temperature ranging between $1050^{\circ} \mathrm{C}$ and $1210^{\circ} \mathrm{C}$ and pressure between $15-20 \mathrm{kbar}$. Based on the study and information for [52], produced by the recent basaltic flows in Ethiopian rift as a small degree partial melting peridotite of $15-25 \mathrm{kbar}$. Also [53] suggested that the basaltic flows from central France are similar in their mineralogy of central Jordan volcano, and were produced by partial melting of spinel lherzolite at 16 - $20 \mathrm{kbar}$ pressure. The basalt flow from El-Lajjoun, Ar-Rabba, Zarqa-Ma'in Atarous and Ash-Shun Ash-Shamaliyya areas of central and northwest Jordan, is produced within the intraplate to continental calc-alkaline to alkali basalt [17] [25] [26] [27] [45], these results documented to the JDB is from the same sources product.

The primary alkali basalts can be formed by low degree of melting, as they are similar in their mineralogy to those of central Jordan volcano produced by partial melting of spinel lherzolite at 16 - 20 kbar pressure [17] [54] [55]. The geophysical methods for seismic and gravity data are indications that the crust thickness below this field is about $35 \mathrm{~km}$ [56]. After all the information obtained for the JDB study, I suggested that the source of the JDB is the contribution within Arabian intraplate basalt produced by numerous Cenozoic intraplate volcanic fields, throughout the melting upper mantle wedge material fertilized during Pan-African subduction and incorporated into the Arabian, Lithospheric mantle [57]. According to [58], had reported to that seem to be originated Arabian lithosphere in the region from depths of $\sim 85 \mathrm{~km}$.

\section{Conclusions}

The Jurf Ed Darawish basalt (JDB) was introduced within intraplate to alkali basalt in Miocene to Pleistocene volcanism field at central Jordan. The study area covered the western part of Jurf Ed Darawish village, about $20 \mathrm{Km}^{2}$, including the Tell El Qirana area. The following is the conclusion of the present study:

1) The mineral composition of basaltic rock samples study (JDB) is as follows: plagioclase, pyroxene (diopside-Augite) and olivine. Secondary minerals such as iddingsite are produced by alteration of olivine crystal and calcite. The accessory 
minerals include apatite and opaque minerals, magnetite. The texture observed was aphanitic, porphyritic, trachytic, glomeroporphyritic, sub ophitic, vesicular, and amygdaloidal texture.

2) The chemical classification of JDB as basalt, Trachy basalt to basalt picrite, had Alkaline to sub-alkaline with respect silica content under saturated silica $\left(\mathrm{SiO}_{2}\right)$. The discrimination diagram showed that the JDB rock samples studied were plotted within the calcalkaline basalt field and continental basaltic field. The alkali basalt rocks can be formed by low degree of melting at a pressure as low as $13 \mathrm{kbar}$ and can fractionate to tholeiitic liquids between 4 and $12 \mathrm{kbar}$.

3) The Cenozoic interpalate volcanic fields throughout form Arabia may be the product for the melting of upper mantle wedge material, fertilized during Pan-African subduction and incorporated into the Arabian Lithospheric mantle. The alkali basalt melts can be derived for $5 \%$ partial melting approximate depths 85 - $95 \mathrm{~km}$ within $30 \mathrm{kbar}$ and $10 \%$ partial melting in the Lithosphere, at 60 - 90 $\mathrm{km}$ within $19-27 \mathrm{kbar}$, and the recent study, concluded that to originated Arabian lithosphere from depths of $\sim 85 \mathrm{~km}$.

4) The $\mathrm{Mg} \#$ values $\left(\mathrm{Mg}^{+2} /\left(\mathrm{Mg}^{+2}+\right.\right.$ Total $\left.\mathrm{Fe}\right)$ ranging from 30 to 53 , it could be pointed to the little fractional crystallization and removal of olivine and pyroxene. The concentration of $\mathrm{Cr}$ and $\mathrm{Ni}$ varies between 23 to $221 \mathrm{ppm}$ and 14 to 51 ppm, respectively. These concentrations contribute to some degree of olivine fractionation, and tend to increase the incompatible trace element concentration in the studied basalts (JDB).

5) The spider diagram for Primordial mantle shows the rock samples study (JDB) enrichment of the incompatible LILE such as $\mathrm{Ba}$ and $\mathrm{K}$, depletion of $\mathrm{Ce}$ relatively to $\mathrm{K}$, and enrichment $\mathrm{Nb}$ and $\mathrm{Pb}$ with depletion of $\mathrm{Y}$ and positive $\mathrm{Nb}$, $\mathrm{Zr}$ and $\mathrm{Ti}$ anomalies. Negative anomalies of $\mathrm{Ba}, \mathrm{Sr}, \mathrm{Ti}$ and $\mathrm{P}$ may be attributed to the fractionation of feldspar for $\mathrm{Ba}$ and $\mathrm{Sr}$ depletion apatite for $\mathrm{P}$ depletion.

6) The source of the JDB is the contribution within Arabian intraplate basalt produced by numerous Cenozoic intraplate volcanic fields, throughout of melting upper mantle wedge material fertilized during Pan-African subduction and incorporated into the Arabian, Lithospheric mantle. The positive Nb peak conforms to the tertiary to recent continental alkali basalt provinces, which conforms to recent continental alkali basalt provinces; these indicate the JDB produced of lithosphere from upwelling asthenosphere mantle.

\section{Acknowledgements}

The author is thankful to the laboratory of the University of $\mathrm{Al}$ al-Bayt University, Institute of Earth and Environmental Sciences for the geochemical and thin section preparation samples. Thanks to the Water Environment and Arid Region Research Center Labs at $\mathrm{Al}$ al-Bayt University for analysis of major elements using X-Ray Florescence Spectrometry (XRF) and trace elements using Atomic Absorption Spectrophotometer (AAS) and Ion Conductive Plasma (ICP). The author is very grateful to Mr. Adnan Mashaqbeh for assisting in the 
preparation of thin sections, at the Institute of Earth and Environmental Sciences labs, $\mathrm{Al}$ al-Bayt University.

\section{Conflicts of Interest}

The author declares no conflicts of interest regarding the publication of this paper.

\section{References}

[1] Bender, F. (1974) Geology of the Arabian Peninsula, Jordan. In: Open-File Report, US Geological Survey, Reston, VA, 560-561. https://doi.org/10.3133/ofr74215

[2] El-Hasan, T. and Al-Malabeh, A. (2008) Geochemistry, Mineralogy and Petrogenesis of El-Lajjoun Pleistocene Alkali Basalt of Central Jordan. Jordan Journal of Earth and Environmental Sciences, 1, 53-62.

[3] Shaw, J.E., Baker, J.A., Menzies, M.A., Thirlwall, M.F. and Ibrahim, K.M. (2003) Petrogenesis of the Largest Intraplate Volcanic Field on the Arabian Plate (Jordan): A Mixed Lithosphere-Asthenosphere Source Activated by Lithospheric Extension. Journal of Petrology, 44, 1657-1679. https://doi.org/10.1093/petrology/egg052

[4] Barberi, F., Capaldi, P., Gasperihi, G., Marinelli, G., Santacroce, R., Treuil, M. and Varet, J. (1979) Recent Basaltic Volcanism of Jordan and Its Implication on the Geodynamic History of the Dead Sea Shear Zone. Geodynamic Evolution of the Afro-Arabian Rift System, 47, 667-683.

[5] Ibrahim, K. and Al-Malabeh, A. (2006) Geochemistry and Volcanic Features of Harrat El-Fahda, a Young Volcanic Field in Northwest Arabia, Jordan. Journal of Asian Earth Sciences, 27, 147-154. https://doi.org/10.1016/j.jseaes.2005.01.009

[6] Moffat, D. (1988) A Volcano Tectonic Analysis of the Cenozoic Continental Basalts of Northern Jordan: Implications for Hydrocarbon Prospectively in the Block B Area. Unpublished Report, University College of Swansea, Swansea.

[7] Abu-Mahfouz, I.S., Al-Malabeh, A.A. and Rababeh, S.M. (2016) Geo-Engineering Evaluation of Harrat Irbid Basaltic Rocks, Irbid District-North Jordan. Arabian Journal of Geosciences, 9, 412-421. https://doi.org/10.1007/s12517-016-2428-4

[8] Camp, V. and Roobol, M. (1992) Upwelling Asthenosphere beneath Western Arabian and Its Regional Implication. Journal of Geophysical Research, 97, 15255-15271. https://doi.org/10.1029/92JB00943

[9] Steinitz, G. and Baratov, Y. (1992) The Miocene-Pleistocene history of the Dead Sea Segment of the Rift in Light or K-Ar Age of Basalts. Israel Journal of Earth Sciences, 40, 199-208.

[10] Moumani, K. (1997) The Geology of Al Husayniyya Al Janubiyya (Jurf Ed Darawish) Area Map Sheet No. 3151-II. Natural Resources Authority, Geology Directorate, Geological Mapping Division, Amman. Jordan.

[11] Hatcher Jr., R., Zietz, I., Regan, R.D. and Abu-Ajammieh, M. (1981) Sinistra Strike-Slip Motion on the Dead Sea Rift: Confirmation from New Magnetic Data. Geology, 9, 458-462. https://doi.org/10.1130/0091-7613(1981)9<458:SSMOTD>2.0.CO;2

[12] Hollocher, K. (2004) CIPW Norm Calculation Program. Geology Department, Union College.

[13] Yazdi, A., Ashja-Ardalan, A., Emami, M., Dabiri, R. and Foudazi, M. (2017) Chemistry of Minerals and Geo Thermobarometry of Volcanic Rocks in the Region Lo- 
cated in Southeast of Bam Kerman Province. Open Journal of Geology, 7, 1644-1653. https://doi.org/10.4236/ojg.2017.711110

[14] Morimoto, N. (1988) Nomenclature of Pyroxenes. Mineralogical Magazine, 52, 535-550. https://doi.org/10.1180/minmag.1988.052.367.15

[15] Lucia, C.M., Hildor, J.S. and Leila, S.M. (2018) Geology, Geochemistry and Petrology of Basalts from Paraná Continental Magmatic Province in the Araguari, Uber lândia, Uberaba and Sacramento Regions, Minas Gerais State, Brazil. Brazilian Journal of Geology, 48, 221-241. https://doi.org/10.1590/2317-4889201820170091

[16] Al-Malabeh, A. (2009) Cryptic Mantle Metasomatism: Evidences from Spinel Lherzolite Xenoliths/Al-Harida Volcano in Harrat Al-Shaam, Jordan. American Journal of Applied Sciences, 6, 2085-2092. https://doi.org/10.3844/ajassp.2009.2085.2092

[17] Al-Fugha, H. and Bany Yaseen, I.A.A. (2019) Petrography, Geochemistry and Petrogensis of Pleistocene Basaltic Flow from Northwest Atarous Area, Central Jordan. International Journal of Geosciences, 10, 613-631. https://doi.org/10.4236/ijg.2019.106035

[18] Le Maitre, R.W., Bateman, P., Dudek, A., Keller, J., Lameyre Le Bas, M.J., Sabine, P.A., Schmid, R., Sorensen, H., Streckeisen, A., Woolley, A.R. and Zanettin, B. (1989) A Classification of Igneous Rocks and Glossary of Terms. Blackwell, Oxford.

[19] Cox, K., Bell, J. and Pankhurst, R. (1979) The Interpretation of Igneous Rocks. Springer, London. https://doi.org/10.1007/978-94-017-3373-1

[20] Winchester, J.A. and Floyd, P.A. (1977) Geochemical Discrimination of Different Magma Series and Their Differentiation Products Using Immobile Elements. Chemical Geology, 20, 325-343. https://doi.org/10.1016/0009-2541(77)90057-2

[21] Watts, B.G., Bennett, M.E., Kopp, O.C. and Mattingly, G.L. (2004) Geochemistry and Petrography of Basalt Grindstones from the Karak Plateau, Central Jordan. Geoarchaeology, 19, 47-69. https://doi.org/10.1002/gea.10103

[22] Ma, G.S.-K., Malpas, J., Xenophontos, C. and Chan, G.H.-N. (2011) Petrogenesis of Latest Miocene-Quaternary Continental Intraplate Volcanism along the Northern Dead Sea Fault System (Al-Ghab-Homs Volcanic Field), Western Syria: Evidence for Lithosphere-Asthenoshere Interaction. Journal of Petrology, 52, 401-430. https://doi.org/10.1093/petrology/egq085

[23] Shaw, J. (2003) Geochemistry of Cenozoic Volcanism and Arabian Lithospheric Mantle in Jordan. Unpublished Ph.D. Thesis, University of London, London.

[24] Wilson, M. (1989) Igneous Petrogensis. Unwin Hyman Ltd., London, 466. https://doi.org/10.1007/978-1-4020-6788-4

[25] Bany Yaseen, I.A. (2014) Contribution to the Petrography, Geochemistry, and Petrogensis of Zarqa-Ma'in Pleistocene Alkali Olivine Basalt Flow of Central Jordan. International Journal of Geosciences, 5, 657-672. https://doi.org/10.4236/ijg.2014.56059

[26] Bany Yaseen, I.A. (2016) Petrography, Geochemistry and Petrogensis of Basal Flow from Ar-Rabba Area, Central Jordan. International Journal of Geosciences, 7, 378-396. https://doi.org/10.4236/ijg.2016.73030

[27] Bany Yaseen, I. and Abidrabbu, A. (2016) Mineralogy, Petrology and Geochemistry of the Basalt Flows at Ash-Shun Ash-Shamaliyya Area, North West Jordan. Earth Sciences, 5, 82-95.

[28] Al Smadi, A., Al-Malabeh, A. and Odat, S. (2018) Characterization and Origin of Selected Basaltic Outcrops in Harrat Irbid (HI), Northern Jordan. Jordan Journal of Earth and Environmental Sciences, 9, 185-196. 
[29] Le Bas, M.J., Le Maitre, R.W., Streckeisen, A. and Zanetin, B. (1986) A Chemical Classification of Volcanic Rocks Based on the Total Alkalies-Silica Diagram. Journal of Petrology, 27, 745-750. https://doi.org/10.1093/petrology/27.3.745

[30] Winter, J.D. (2001) An Introduction to Igneous and Metamorphic Petrology. Prentice Hall Inc., Upper Saddle River, NJ, 697.

[31] Alnawafleh, H., Tarawneh, K., Ibrahim, K., Zghoul, K., Titi, A., Rawashdeh, R., Moumani, K. and Masri, A. (2015) Characterization and Origin of the Miocene Mudawwara-Quwayra Basaltic Dike, Southern Jordan. International Journal of Geosciences, 6, 869-881. https://doi.org/10.4236/ijg.2015.68071

[32] Pearce, J.A. and Cann, J.R. (1973) Tectonic Setting of Basic Volcanic Rocks Determined Using Trace Element Analyses. Earth and Planetary Science Letters, 19, 290-300. https://doi.org/10.1016/0012-821X(73)90129-5

[33] Brian, M. and Carleton, B.M. (1982) Principles of Geochemistry. 4th Edition, John Wiley \& Sons, New York, 350.

[34] Gunter, F. (1998) Principles and Applications of Geochemistry. 2nd Edition, Prentice-Hall, Inc., Upper Saddle River, NJ.

[35] Klein, C. and Hurlbut, J. (1993) Manual of Mineralogy. John Wiley and Sons, New York, 596.

[36] Pearce, J., Harris, N. and Tindle, A. (1984) Trace Element Discrimination Diagram for the Tectonic Interpretation of Granitic Rocks. Journal of Petrology, 25, 956-983. https://doi.org/10.1093/petrology/25.4.956

[37] Irvin, T.N. and Baragar, W.R. (1971) A Guide to the Chemical Classification of the Volcanic Rocks. Canadian Journal of Earth Sciences, 8, 523-548.

[38] Pearce, T.H., Gorman, B.E. and Birkett, T.C. (1977) The Relationship between Major Element Chemistry and Tectonic Environment of Basic and Intermediate Volcanic Rocks. Earth and Planetary Science Letters, 36, 121-132. https://doi.org/10.1016/0012-821X(77)90193-5

[39] Al-Fugha, H. and Al-Amaireh, M. (2007) Petrology and Origin of Ultramafic Xenoliths from Northeastern Jordan Volcanoes. American Journal of Applied Sciences, 4, 491-495. https://doi.org/10.3844/ajassp.2007.491.495

[40] Rollinson, H. (1993) Using Geochemical Data, Evaluation, Presentation, Interpretation, Longman Scientific and Technical. John Wiley \& Sons, Inc, New York.

[41] Jenner, G., Gawood, P., Rautenschlein, M. and White, W. (1987) Composition of Back-Arc Basin Volcanic Valufa Ridge Lau Basin: Evidence for a Slab-Derived Component in Their Mantle Source. Journal of Volcanology and Geothermal Research, 32, 209-222. https://doi.org/10.1016/0377-0273(87)90045-X

[42] Moghazi, A.M. (2003) Geochemistry and Petrogensis of a High-K Calc-Alkaline Dokhan Volcanic Suite, South Safaga Area, Egypt: The Role of Late Neoproterozoic Crustal Extension. Precambrian Research, 125, 161-178. https://doi.org/10.1016/S0301-9268(03)00110-4

[43] Sun, S.S. and Mac Donough, W.F. (1989) Chemical and Isotopic Systematic of Oceanic Basalts: Implications for Mantle Composition and Processes in Magmatism in the Ocean Basins. Geological Society, London, Special Publication, 42, 313-345. https://doi.org/10.1144/GSL.SP.1989.042.01.19

[44] El-Akhal, H. (2004) Contribution to the Petrography, Geochemistry and Tectonic Setting of the Basalt Flows of the Umm-Qais Plateau, North Jordan. Geological Bulletin of Turkey, 47, 1-10. 
[45] Fediuk, F. and Al-Fugha, H. (1999) Dead Sea Region Fault-Controlled Chemistry of Cenozoic Volcanics. Geolines (Praha), 9, 29-34.

[46] Uslular, G. and Gençalioğlu-Kuşcu, G. (2019) Geochemical Characteristics of Anatolian Basalts: Comment on "Neogene Uplift and Magmatism of Anatolia: Insights from Drainage Analysis and Basaltic Geochemistry" by McNab Et Al. Geochemistry, Geophysics, Geosystems, 20, 530-541.

[47] Al-Fugha, H. (1995) Spinel-Lherzolite Xenoliths from Jabal Al-Qiranah Basalt Central Jordan. Mutah Journal, 10, 1-14.

[48] Al-Fugha, H. (2006) Petrology and Geochemistry of Upper Mantle Xenoliths from Tel-Remah Volcano. NE Jordan Mutah Journal, 21, 17-30.

[49] Shaw, J.E., Baker, J.A., Kent, A.R., Ibrahim, K.M. and Menzies, M.A. (2007) The Geochemistry of the Arabian. Lithospheric Mantle a Source for Intraplate Volcanism. Journal of Petrology, 48, 1495-1512. https://doi.org/10.1093/petrology/egm027

[50] Shervais, J.W. and Vetter, S.K. (2009) High-K Alkali Basalts of the Western Snake River Plain: Abrupt Transition from Tholeitic to Mildly Alkaline Plume-Derived Basalts. Journal of Volcanology and Geothermal Research, 188, 141-152.

https://doi.org/10.1016/j.jvolgeores.2009.01.023

[51] Green, D.H. (1970) A Review of Experimental Evidence on the Origin of Basaltic and Nephelinitic Magmas. Physics of the Earth and Planetary Interiors, 3, 221-235. https://doi.org/10.1016/0031-9201(70)90060-9

[52] Rooney, T.O., Furma, T., Yirgu, G. and Ayalew, D. (2005) Structure of Ethiopian Lithophere: Xenolith Evidence in the Main Ethiopian Rift. Geochimica et Cosmochimica Acta, 69, 3889-3910. https://doi.org/10.1016/j.gca.2005.03.043

[53] Thompson, R.N., Gibson, L., Marriner, G.F., Mattey, D.P. and Morrison, M.A.J. (1980) Trace-Element Evidence of Multistage Mantle Fusion and Polybaric Fractional Crystallization in the Palaeocene Lavas of Skye, NW Scotland. Journal of Petrology, 21, 265-293. https://doi.org/10.1093/petrology/21.2.265

[54] Al-Safarjalani, A., Nasir, S., Fockenberg, T. and Massonne, H.-J. (2009) Chemical Composition of an Intermediate Part of the Lower Crust beneath South Western Syria: Characterization of the Upper Part of the Lower Crust beneath the Arabian Plate. Geochemistry, 69, 359-375. https://doi.org/10.1016/j.chemer.2009.05.005

[55] Shervais, J.W., Reagan, M., Haugen, E., Almeev, R.R., Pearce, J.A., Prytulak, J., Ryan, J.G., Whattam, S.A., Godard, M., Chapman, T., Li, H., Kurz, W., Nelson, W.R., Heaton, D., Kirchenbaur, M., Shimizu, K., Sakuyama, T., Li, Y. and Vetter, S.K. (2018) Magmatic Response to Subduction Initiation: Part 1. Fore-Arc Basalts of the Izu-Bonin Arc from IODP Expedition 352. Geochemistry, Geophysics, Geosystems, 20, 314-338.

[56] Sawaf, T., Al-Saad, D., Gebran, A., Barazangi, M., Best, A. and Chiamov, T. (1993). Stratigraphy and Structure of Eastern Syria across the Euphrates Depression. Tectonophysics, 230, 267-281. https://doi.org/10.1016/0040-1951(93)90235-C

[57] Thompson, R.N. (1987) Phase-Equilibria Constraints on the Genesis and Magmatic Evolution of Oceanic Basalts. Earth-Science Reviews, 24, 161-210. https://doi.org/10.1016/0012-8252(87)90023-7

[58] Özdemir, Y., Mercan, Ç., Oyan, V. and Özdemir, A.A. (2019) Composition, Pressure, and Temperature of the Mantle Sources Region of Quaternary Nepheline-Basanitic Lavas in Bitlis Massif, Eastern Anatolia, Turkey: A Consequence of Melts from Arabian Lithospheric Mantle. Lithos, 328-329, 115-129.

https://doi.org/10.1016/j.lithos.2019.01.020 